\title{
KOMPOSISI IODIUM PADA PRODUK MANISAN RUMPUT LAUT
}

\author{
(The Iodine Composition of Seaweed Sweet Product)
}

\author{
Eunike L. Mongi, Silvana D. Harikedua, Lita A.D.Y. Montolalu \\ Staf Pengajar pada Program Studi Teknologi Hasil Perikanan FPIK UNSRAT Manado.
}

\begin{abstract}
ABSTRAK
Rumput laut jenis Kappaphycus alvarezii digunakan sebagai bahan baku dalam penelitian ini. Rumput laut ini dipotong dengan ukuran 5 dan $15 \mathrm{~cm}$. Tujuan penelitian ini adalah untuk melihat seberapa banyak nutrisi iodium yang hilang selama proses pengolahan manisan pada 2 ukuran potong rumput laut yang berbeda. Penelitian ini menggunakan Rancangan Acak Lengkap (RAL) dengan pola percobaan faktorial $1 \times 2$, kombinasi perlakuan diulang sebanyak 2 kali sehingga diperoleh 4 satuan percobaan. Uji ortogonal kontras digunakan untuk melihat apakah ada perbedaan antara dua jenis ukuran potong. Pengamatan dilakukan selama proses pencucian, perendaman dan terhadap produk manisan. Tahapan pengamatan sebagai berikut: pencucian (rumput laut dan air cucian), 3 kali perendaman (rumput laut dan air rendaman) dan dalam bentuk produk manisan. Analisa data menunjukkan bahwa proses pencucian dan perendaman mempengaruhi komposisi iodium pada rumput laut. Kadar iodium $K$. alvarezii mengalami penurunan selama proses pencucian dan perendaman juga pada pengolahan manisan. Hasil uji ortogonal kontras menunjukkan ukuran potong tidak berpengaruh terhadap kadar iodium manisan rumput laut. Secara umum, proses pengolahan manisan rumput laut tidak menyebabkan kehilangan komponen nutrisi iodium yang berarti.
\end{abstract}

Kata kunci: Iodium, Pencucian, Perendaman, Pemasakan.

Kappaphycus alvarezii were used as a raw material of this research. Those were sliced into two different sizes, $5 \mathrm{~cm}$ and $15 \mathrm{~cm}$, in order to determine how much nutrition was lost for the two different size and as well as how slice size that affected iodine composition in the final seaweed sweet product. The completely random design with a 1 by 2 factorial experimental pattern, treatment combinations were repeated two times with total of 4 experimental units. To compare the composition of iodine in two size of seaweed used an orthogonal contrast test was performed. The sequence of observation were followed: washing (seaweed and washing water), 3 times of soaking (seaweed and soaking water), and the production of seaweed sweet. Analysis in iodine content in $K$. alvarezii $1.2 \%$ respectively and then showed a decrease after the final soaking process, i.e. $0.45 \%$ and $0.7 \%$ respectively. This means that more iodine composition was split into the washing water by $K$. alvarezii $0.7 \%$ respectively. The result of analysis variance on iodine content did not find an interaction between two seaweed slice sizes. Orthogonal contrast test showed that there slice size had no effect on sweet iodine content. Seaweed have the necessary characteristics to be used as raw material for processed seaweed products, especially because of their iodine composition. Changes in the composition of iodine during preparation processes do not constitute significant nutrition component losses.

Keywords: Iodine, Washing, Soaking, Cooking.

\section{PENDAHULUAN}

Rumput laut merupakan bagian terbesar tanaman laut yang sejak dahulu hingga sekarang digunakan sebagai bahan dan obatobatan. Keunggulan dari rumput laut yakni kandungan dietary fiber atau serat makanan dan juga mineral terutama iodium yang tinggi. Iodium digolongkan sebagai unsur mikro (trace element) yang dibutuhkan oleh tubuh (Gaman dan Sherington, 1992). Jumlah iodium orang dewasa diperkirakan 9-10 mg. Dua pertiga dari jumlah tersebut terkumpul dalam kelenjar tiroid (kelenjar gondok). Tiroksin merupakan hormon utama yg dikeluarkan oleh kelenjar tiroid.
Setiap molekul tiroksin mengandung empat atom iodium. Fungsi iodium yakni sebagai komponen esensial tiroksin dan kelenjar tiroid, sehingga jika manusia kekurangan iodium dapat menyebabkan penyakit gondok (Fennema, 1976). Kandungan iodium yang tinggi pada rumput laut merupakan alasan mengapa penyakit gondok di Jepang hanya sekitar 1 dari sekitar 1 juta penduduk, sedangkan di Indonesia sekitar 8 dari 100 penduduk atau sekitar $8 \%$ (Winarno, 1990).

Iodium yang ada pada air laut terdapat dalam konsentrasi yang sangat rendah, tetapi organisme yang hidup di laut memiliki 
kemampuan untuk menghimpunnya (Gaman dan Sherington, 1992). Ikan laut dan rumput laut merupakan sumber iodium yang sangat baik karena kandungan iodiumnya yang cukup tinggi. Kandungan iodium ikan laut sebanyak 16,5-143,3 ug/100 gr atau 28 kali ikan air tawar, sedangkan kandungan iodium rumput laut sekitar 2.400-155.000 kali kandungan iodium sayuran yang tumbuh di darat (Berhimpon, 1999).

Iodium diperoleh dari garam dapur yang digunakan sebagai bahan tambahan makanan sehari-hari. Sedangkan kita tahu bersama selama proses pembuatan garam, iodium yang ada secara alami pada air laut ikut menguap pada proses tersebut. Oleh sebab itu iodium sengaja ditambahkan pada garam, sehingga garam tersebut menjadi garam beriodium.

Namun, selama proses pengolahan makanan, iodium dapat hilang lewat penguapan akibat proses pemanasan. Oleh sebab itu kita dianjurkan untuk mengkonsumsi makanan yang mengandung iodium sebagai tindakan pencegahan timbulnya penyakit gondok akibat hilangnya nutrisi iodium selama proses pengolahan makanan. Mengkonsumsi rumput laut merupakan salah tindakan pencegahan.

Penelitian ini dilaksanakan untuk mengetahui perubahan komposisi iodium selama proses pengolahan rumput laut. Kita tahu bersama, sebelum diolah lebih lanjut, rumput laut harus melalui beberapa tahap penanganan seperti pencucian dan perendaman. Oleh karena itu dilakukan penelitian terhadap kedua tahap tersebut yang mencakup air cucian, air rendaman dan rumput laut itu sendiri. Dengan tujuan untuk melihat sejauh mana perubahan komposisi iodium yang terjadi selama proses pencucian dan perendaman. Dan lebih lanjut dilakukan pengamatan hingga dalam bentuk produk manisan rumput laut. Pengolahan produk ini merupakan salah satu upaya diversifikasi produk rumput laut yang berskala rumah tangga.

\section{METODOLOGI PENELITIAN}

\section{Bahan dan Peralatan Penelitian}

Bahan yang akan diteliti adalah rumput laut Kappaphycus alvarezii yang merupakan jenis alga merah dan memiliki nilai komersil penting.

Pencucian dan perendaman menggunakan akuades. Untuk membuat manisan menggunakan bahan-bahan tambahan yakni gula pasir, vanilin dan asam sitrat.

Untuk analisa kandungan iodium, menggunakan Metode Furman yaitu metode Kolorimeter dengan bahan sebagai berikut: sebagai pereaksi larutan $\mathrm{NaOH} 1 \%, \mathrm{H}_{2} \mathrm{O}_{2} 3 \%$, $\mathrm{H}_{2} \mathrm{SO}_{4}$ 1:10, larutan $\mathrm{O}$ toulene $67 \%$ dalam etanol, kristal $\mathrm{Fe}_{2} \mathrm{SO}_{4}$ (besi sulfat).

\section{Tata Laksana Penelitian}

Rumput laut dicuci dengan akuades, sambil dibersihkan dari kotoran dan benda asing yang melekat. Selanjutnya proses perendaman selama 30 jam yang terdiri dari 3 kali perendaman dengan interval waktu 10 jam dengan tahapan perendaman sebagai berikut: perendaman I pada jam 08.00-18.00, perendaman II 18.00-04.00 dan perendaman III 04.00-14.00. Setelah proses perendaman, rumput laut ditiriskan lalu dipotong-potong dengan ukuran $5 \mathrm{~cm}$ dan $15 \mathrm{~cm}$, kemudian siap untuk diproses manisan rumput laut.

\section{HASIL DAN PEMBAHASAN}

Tabel 1. Komposisi Iodium Pada Rumput Laut Kering, Pencucian dan Perendaman (ppm).

\begin{tabular}{cccccc}
\hline \multirow{2}{*}{ Jenis Rumput Laut } & \multirow{2}{*}{ Kering } & \multirow{2}{*}{ Pencucian } & \multicolumn{3}{c}{ Perendaman } \\
& & & II & III \\
\hline K. alvarezii & 17 & 12 & 13 & 8 & 7 \\
\hline
\end{tabular}

Pada proses pencucian dan perendaman koposisi iodium rumput laut mengalami penurunan dengan pemahaman bahwa ada kadar iodium yang terlarut selama proses perendaman dan pencucian. Hein dan Best (1980) menyatakan bahwa natrium iod kalium iod bersifat larut dalam air. Lebih jelasnya dapat dilihat pada Tabel 2 .

Tabel 2. Komposisi Iodium Pada Air Cucian dan Air Rendaman (ppm).

\begin{tabular}{ccccc}
\hline \multirow{2}{*}{ Jenis Rumput Laut } & \multirow{2}{*}{ Air Cucian } & \multicolumn{3}{c}{ Air Rendaman } \\
& & I & II & III \\
\hline K. alvarezii & $*$ & 13 & 6 & 7,5 \\
\hline *Tidak Terdeteksi & & & &
\end{tabular}

Tabel 3. Komposisi Iodium Pada Manisan Rumput Laut (ppm).

\begin{tabular}{cccc}
\hline \multirow{2}{*}{ Jenis Rumput Laut } & \multirow{2}{*}{ Ulangan } & \multicolumn{2}{c}{ Ukuran Potong } \\
& & $\mathbf{5} \mathbf{~ c m}$ & $\mathbf{1 5} \mathbf{~ c m}$ \\
\hline K. alvarezii & 1 & 4 & 15 \\
& 2 & 3 & 2 \\
\hline
\end{tabular}

Data menunjukkan terjadi penurunan komposisi iodium selama proses pengolahan rumput laut mentah menjadi produk manisan. Hal ini disebabkan karena adanya proses pemanasan selama pengolahan manisan rumput laut. Menurut Tannembaun et.al. (1980) dalam 
Fenema (1985), kehilangan berbagai bentuk iodium dari pangan belum diteliti secara luas, tetapi kehilangan secara nyata nampak pada proses bleaching, cooking dan blanching.

Sebelumnya pendapat yang serupa dikemukakan oleh Gladies dan Miller (1962), bahwa pelunakan struktur jaringan selama perendaman atau pemasakan, membolehkan banyak nutrien untuk larut dalam air perendaman dan pemasakan.

\section{KESIMPULAN}

Berdasarkan hasil penelitian dapat diketahui bahwa proses pengolahan manisan rumput laut yang mencakup pencucian, perendaman dan pemasakan (pemanasan) dapat menyebabkan perubahan komposisi iodium, namun perubahan yang terjadi tidak menyebabkan kehilangan komponen nutrisi iodium yang berarti pada bahan baku. Demikian juga dengan ukuran potongan dan berdasarkan hasil uji ortogonal kontras tidak memberikan pengaruh yang nyata pada komposisi iodium. Hal ini mengartikan bahwa, proses pengolahan berpengaruh terhadap komposisi nutrisi iodium pada rumput laut, namun tidak mengurangi nilai nutrisi manisan rumput laut.

\section{DAFTAR PUSTAKA}

Berhimpon, S. 1999. Rumput Laut Sebagai Sumber Mineral dan Potensi Sayuran Dari Laut. Dalam Prosiding Seminar Sehari Memperingati Hari Pangan Sedunia. PATPI Sulawesi Utara, Manado 22 Oktober 1999.

Fennema O.R, 1985. Food Chemistry. Second Edition, Revised and Expanded. Marcel Dekker Inc, New York and Bassel.

Gaman, P.M and K.B Sherrington ., 1992. The Science Of Foods. An Introduction to Food Science, Nutrtion and Microbiology. Second Edition. Pergamon Press Pic. Headington Hill Hall . Oxford OX3 OBW. England.

Gladies, S and B. Miller. Nutrition : An Introduction and Application in Foods. Marcel Dekker Inc, New York.

Winarno, F.G, 1990. Teknologi Pengolahan Rumput Laut. Penerbit Pustaka Sinar Harapan. Jakarta.

Hein $\mathrm{M}$ and L.R Best. College Chemistry. An Introduction to Inorganic, Organic and Biochemistry. $2^{\text {nd }}$ Ed. Brooks Publishing Company Montery, California A Division of Wodswarth, Inc. 